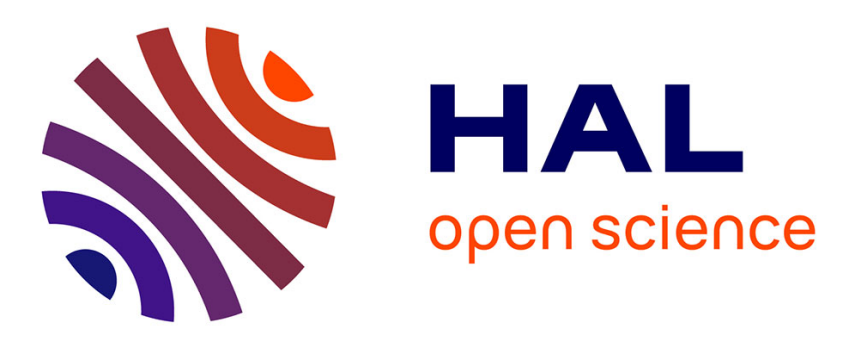

\title{
Nucleophilic Ring Opening of Donor-Acceptor Cyclopropanes Catalyzed by a Brønsted Acid in Hexafluoroisopropanol
}

Edward Richmond, Vuk Vukovic, Joseph Moran

\section{- To cite this version:}

Edward Richmond, Vuk Vukovic, Joseph Moran. Nucleophilic Ring Opening of Donor-Acceptor Cyclopropanes Catalyzed by a Brønsted Acid in Hexafluoroisopropanol. Organic Letters, 2018, 20 (3), pp.574-577. 10.1021/acs.orglett.7b03688 . hal-01872455

\section{HAL Id: hal-01872455 https://hal.science/hal-01872455}

Submitted on 20 Sep 2018

HAL is a multi-disciplinary open access archive for the deposit and dissemination of scientific research documents, whether they are published or not. The documents may come from teaching and research institutions in France or abroad, or from public or private research centers.
L'archive ouverte pluridisciplinaire HAL, est destinée au dépôt et à la diffusion de documents scientifiques de niveau recherche, publiés ou non, émanant des établissements d'enseignement et de recherche français ou étrangers, des laboratoires publics ou privés. 


\title{
Nucleophilic Ring-Opening of Donor-Acceptor Cyclopropanes Cata- lyzed by Bronsted acid in Hexafluoroisopropanol
}

\author{
Edward Richmond, Vuk D. Vuković, Joseph Moran* \\ University of Strasbourg, CNRS, ISIS UMR 7006, 67000 Strasbourg, France \\ Supporting Information Placeholder
}
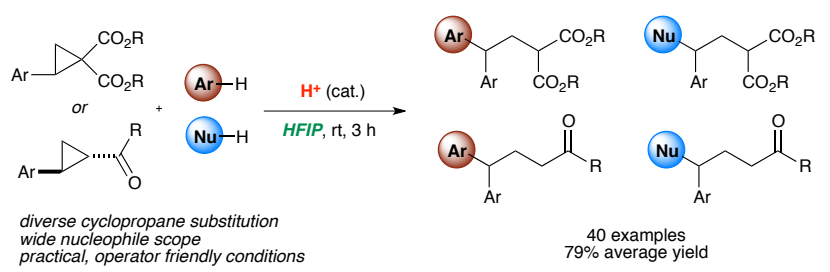

ABSTRACT: A general, Brønsted acid catalyzed method for the room temperature, nucleophilic-ring opening of donor-acceptor cyclopropanes in fluorinated alcohol solvent, HFIP, is described. Salient features of this method include an expanded cyclopropane scope; including those bearing single keto-acceptor-groups, and those bearing electron deficient aryl-groups. Notably, the catalytic system proved amenable to a wide range of nucleophiles including arenes, indoles, azides, diketones and alcohols.

Donor-acceptor (DA) cyclopropanes serve as 'springloaded' synthetic intermediates owing to the inherent $\mathrm{C}-\mathrm{C}$ bond polarization afforded by the synergistic combination of donor- and acceptor substituents. ${ }^{1}$ Consequently, they have found widespread application in modern synthetic organic chemistry, and a range of catalytic methodologies have been developed that engage DA-cyclopropanes in cycloaddition, ${ }^{2}$ 1,3-difunctionalization ${ }^{3}$ and homo-conjugate addition-type reactions ${ }^{4}$ with a variety of nucleophiles including amines, alcohols, thiols, carboxylic acids and azides. ${ }^{5}$ Outside of reactions with heteroatomic nucleophiles, a handful of catalytic arylation reactions of DA-cyclopropanes have been developed, however currently developed systems are typically limited to a single class of nucleophiles such as indole derivatives, ${ }^{6}$ anilines, ${ }^{7}$ electronically-activated anisole derivatives ${ }^{8}$ and 2naphthols. ${ }^{9}$ Typically, all of the aforementioned catalytic systems employ high (10-20 mol\%) loadings of Lewis acidic catalysts, ${ }^{10}$ namely rare-earth triflates, with the reactions typically operating at elevated temperatures. As these Lewis acidic catalyst systems seek to take advantage of dual-coordination to geminal diester-bearing cyclopropanes, a striking limitation in terms of cyclopropane substitution becomes apparent. Likewise, the activation of such donor-acceptor cyclopropanes relies on polarization of the $\mathrm{C}-\mathrm{C}$ bond by the synergistic interaction of the donor and acceptor groupings. Consequently, in almost all conjugate addition-type ring-openings the tolerated donor-substitution is limited to electron-donating or electronneutral aryl-substituents (Figure 1, Top).

Given our recent investigations into aggregation phenomena in acid catalysis ${ }^{11}$ we recognized an opportunity to develop an alternative Brønsted acid-catalyzed protocol for the activation of DA-cyclopropanes. We hypothesized that a strong Brønsted acid catalyst system would provide a dual-advantage in the activation of donor-acceptor cyclopropanes; allowing both a wider nucleophile scope, and the employment of a wider range of cyclopropane scaffolds above and beyond the typical structural limitations.

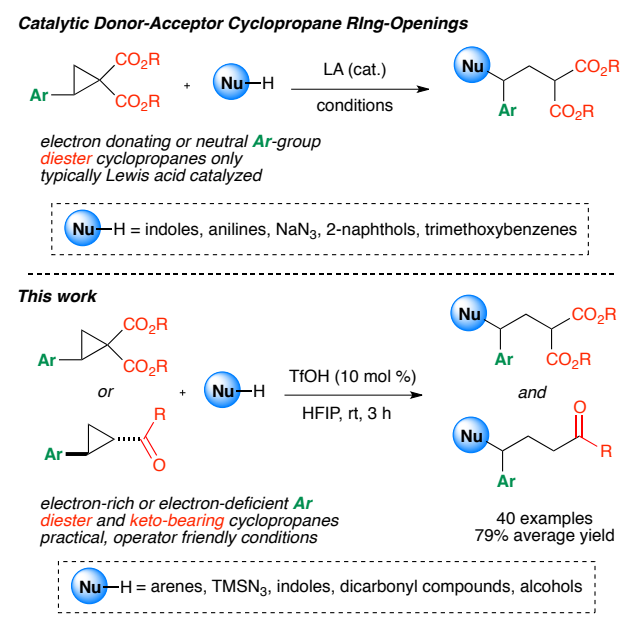

Figure 1. Existing Lewis acid catalyzed methodologies for the nucleophilic ring-opening of diester-bearing D-A cyclopropanes. This work: Brønsted acid catalyzed nucleophilic ringopening of a wide range of donor-acceptor cyclopropanes.

Herein, we report the successful realization of such a scenario, whereby trifluoromethanesulfonic acid (TfOH) in hexafluoroisopropanol (HFIP) ${ }^{12,13}$ acts as a highly active and general catalyst system for the nucleophilic ring-opening of donor-acceptor cyclopropanes. A wide array of nucleophiles $(C$-, $\mathrm{O}-, \mathrm{N}-)$ can be employed in the protocol, and typical limitations of the donor-acceptor cyclopropane architecture have also been surpassed, allowing chalcone derived cyclopropanes bearing a single keto-acceptor motif to engage in catalytic nucleophilic ring-opening (Figure 1 - This work). The devel- 
oped method is also highly user-friendly providing numerous practical advantages; the reactions operate at ambient temperature, under open-flask conditions with most reactions typically complete within 3 hours.

Synthetic investigations began with a benchmark reaction the arylative ring-opening of donor acceptor cyclopropane 1a in combination with 1,3,5-trimethoxybenzene; a reaction known to proceed at $80{ }^{\circ} \mathrm{C}$ in the presence of $20 \mathrm{~mol} \%$ of $\mathrm{Yb}(\mathrm{OTf})_{3} .{ }^{8 \mathrm{c}} \mathrm{It}$ was rapidly established that by slight modification of catalytic conditions already established within the group, ${ }^{11 \mathrm{~d}}$ the arylative ring-opening of such cyclopropanes could be initiated at room temperature by $\mathrm{TfOH}$ when employing HFIP as solvent. Further slight tweaking established 10 $\mathrm{mol} \%$ of TfOH in HFIP as a reliable system for this transformation leading to complete conversion in just 3 hours and a 95\% yield of the desired arylated material $\mathbf{2 a}$ after simple column chromatography (Scheme 1).

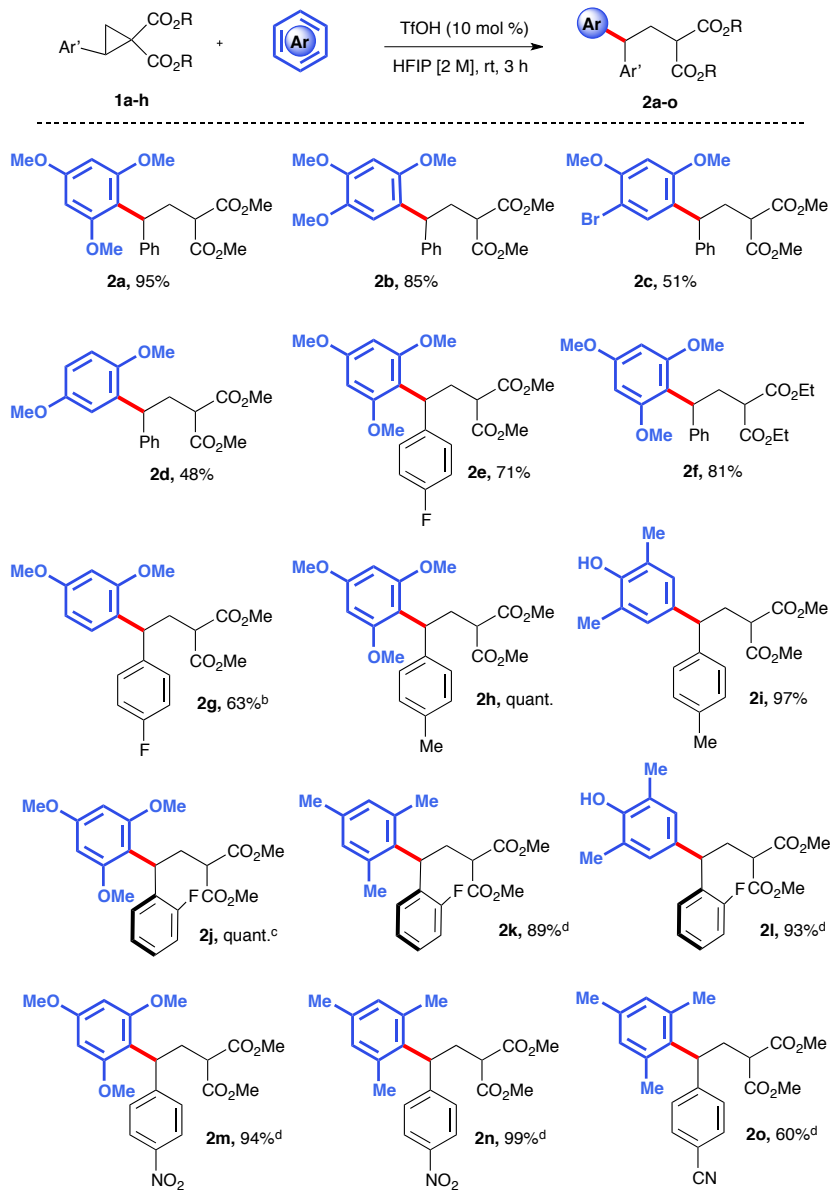

Scheme 1. Scope of Brønsted Acid catalyzed Arylative Ring-Opening of Donor-Acceptor Cyclopropanes bearing a geminal diester motif ${ }^{\text {a }}$ Isolated yields after column chromatography. ${ }^{\mathrm{b}}$ Isolated as a mixture of regioisomers, see SI for further details. ${ }^{\mathrm{c}}$ Reaction performed at $40{ }^{\circ} \mathrm{C}$ for $4 \mathrm{~h}$. ${ }^{\mathrm{d}}$ Reaction performed at $50{ }^{\circ} \mathrm{C}$ for $24 \mathrm{~h}$.

Application of these catalytic reaction conditions across a range of donor-acceptor cyclopropane substrates was then undertaken. 1,2,4-Trimethoxybenzene also proved an excellent nucleophile furnishing the desired product $\mathbf{2 b}$ in $85 \%$ yield. Reaction of various cyclopropane substrates bearing electron donating or neutral aryl-substituents with a range of di- and tri-methoxybenzene derivatives provided the desired arylated products in moderate to good yields $(\mathbf{2 c - 2 h})$ including arylated diethylester 2f. 2,6-Dimethylphenol also proved an excellent nucleophile in this system generating arylated product $\mathbf{2 i}$ in $97 \%$ yield. A donor-acceptor cyclopropane bearing a 2 fluorophenyl substituent was also well tolerated in this catalytic system, delivering arylated products $\mathbf{2} \mathbf{j}, \mathbf{2 k}$, and $\mathbf{2 \mathbf { l }}$ with 1,3,5-trimethoxybenzene, mesitylene and 2,6-dimethylphenol respectively. As a further demonstration of the generality of the developed catalytic system, donor acceptor cyclopropanes bearing a 4-nitrophenyl group and a 4-benzonitrile aryl substituent were also smoothly engaged in arylation with 1,3,5trimethoxybenzene and mesitylene (2m-2o) in good to excellent yields.
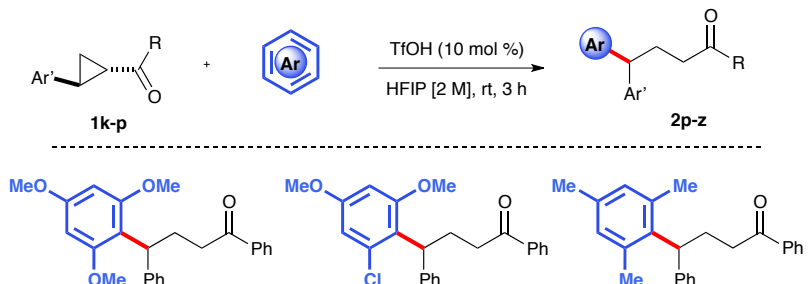

$2 p, 98 \%$

$2 q, 72 \%{ }^{c}$

2 r, $89 \%$<smiles>O=C(CCC(c1ccccc1)c1cccc2ccccc12)C1CCCCC1</smiles><smiles>Cc1cc(C([PH2+])CCC(=O)Nc2ccccc2)cc([N+](=O)[O-])c1O</smiles><smiles>O=C(NCCC([Pb])c1ccc(O)cc1)Nc1ccccc1</smiles>

$2 s, 82 \%^{c}$

2t, $78 \%$

$2 u, 83 \%^{c}$<smiles>COc1cc(OC)c(C(CCC(=O)c2ccccc2)c2ccc(Cl)cc2)c(OC)c1</smiles><smiles>Cc1ccc2cc(C)c(C(CCC(=O)c3ccccc3)c3ccc(Cl)cc3)cc2c1</smiles><smiles>COc1cc(OC)c(C(CCC(=O)c2ccccc2)c2ccc(C(F)(F)F)cc2)c(OC)c1</smiles>

Scheme 2. Scope of Brønsted Acid catalyzed Arylative Ring-Opening of Donor-Acceptor Cyclopropanes bearing a keto-acceptor group ${ }^{\mathrm{a}}$ asolated yields after column chromatography. ${ }^{\mathbf{b}}$ Reaction performed with $5 \mathrm{~mol} \% \mathrm{TfOH}$. ${ }^{\mathrm{C}}$ Isolated as a mixture of regioisomers, see the supporting information for further details. ${ }^{\mathrm{d}}$ Reaction performed at 80 ${ }^{\circ} \mathrm{C}$.

Attention next turned to donor-acceptor cyclopropanes bearing a single ketone substituent as the 'acceptor' motif. To the best of our knowledge, such scaffolds have yet to find widespread uptake as substrates in catalytic cyclopropane methodology development owing to the prior focus on Lewis acid catalyzed methods believed to require a geminal diester cyclopropane substitution pattern. Nevertheless, upon reaction with 1,3,5-trimethoxybenzene, chalcone derived cyclopropane $\mathbf{1 k}$ delivered the desired arylated product $\mathbf{2} \mathbf{p}$ in $98 \%$ yield (Scheme 2). Furthermore, this reaction was successfully scaled up to $2.5 \mathrm{mmol}$, catalyzed by only $5 \mathrm{~mol} \% \mathrm{TfOH}$, and duly delivered $0.971 \mathrm{~g}$ of the arylated product in $99 \%$ yield. Variation of the nucleophilic component in this reaction system proved unproblematic (2q-2s), as did variation of the chalcone-derived cyclopropane scaffold to include electron-rich 
aryl groups (2t and $2 \mathbf{u})$ and halogenated aryls (2v and $2 \mathbf{w})$. Notably, mesitylene (2r), naphthalene derivatives (2s and $\mathbf{2 w}$ ), 2,6-dimethylphenol (2t), and anisole (2u) were all tolerated in the reaction system in excellent yield. Once again, donoracceptor cyclopropanes bearing electron deficient arylsubstituents $\left(4-\mathrm{NO}_{2}\right.$ and $\left.4-\mathrm{CF}_{3}\right)$ were successfully engaged in arylative ring-opening ( $\mathbf{2 x}, \mathbf{2 y}$ and $\mathbf{2 z}$ ) with only moderate heating required in the case of the reactions employing the 4nitro substituted starting material. Additionally, cyclopropanes bearing heterocyclic motifs were also successfully engaged in arylative ring-opening with 1,3,5-trimethoxybenzene under slightly modified conditions; ${ }^{\text {is }}$ thiophene-bearing products $\mathbf{3 a}$ and $3 \mathrm{~b}$ were isolated in $60 \%$ and $93 \%$ yield respectively, yet methyl-furan bearing product $\mathbf{3 c}$ proved sensitive to decomposition during purification and was only isolated in trace amounts (Scheme 3).

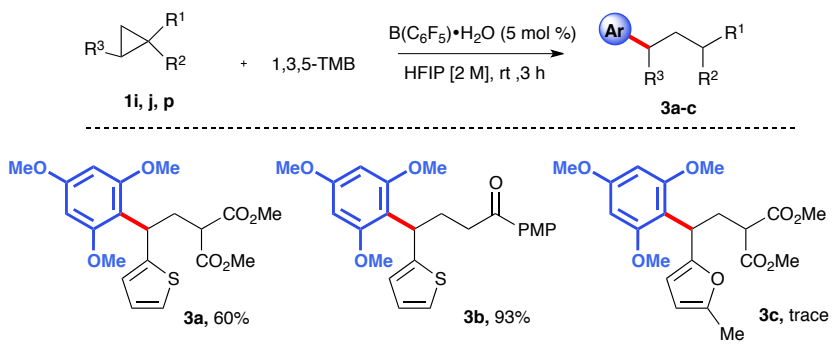

Scheme 3. Brønsted Acid catalyzed Arylative RingOpening of Donor-Acceptor Cyclopropanes bearing heterocyclic donor-groups ${ }^{\mathrm{a}}{ }^{\mathrm{a}}$ Isolated yields after column chromatography.

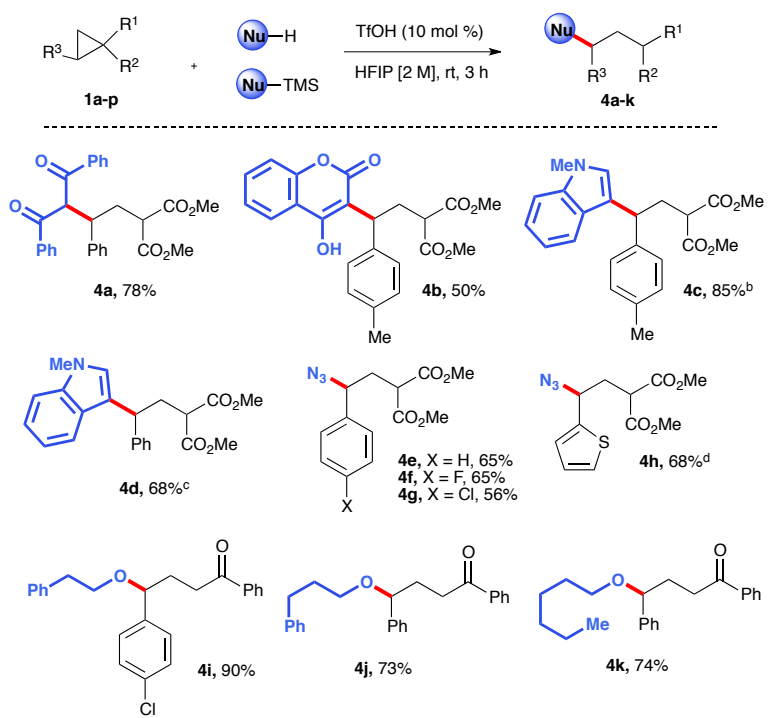

Scheme 4. Scope of Bronsted Acid catalyzed Nucleophilic Ring-Opening of Donor-Acceptor Cyclopropanes ${ }^{\mathbf{a}}$ a Isolated yields after column chromatography. ${ }^{\mathbf{b}}$ Reaction performed with $5 \mathrm{~mol} \% \mathrm{~B}\left(\mathrm{C}_{6} \mathrm{~F}_{5}\right) \cdot \mathrm{H}_{2} \mathrm{O}$ in $\mathrm{MeNO}_{2}$ at $80{ }^{\circ} \mathrm{C}$ for $24 \mathrm{~h}$. ${ }^{\mathrm{c}} \mathrm{Re}-$ action performed with $10 \mathrm{~mol} \% \mathrm{~B}\left(\mathrm{C}_{6} \mathrm{~F}_{5}\right) \cdot \mathrm{H}_{2} \mathrm{O}$ at $80{ }^{\circ} \mathrm{C}$ for 24 h. ${ }^{d}$ Reaction performed with $5 \mathrm{~mol} \% \mathrm{~B}\left(\mathrm{C}_{6} \mathrm{~F}_{5}\right) \cdot \mathrm{H}_{2} \mathrm{O}$.

Further investigation of this reaction system revealed that the same catalytic conditions were able to promote cyclopropane ring-opening with nucleophiles other than activated arenes. Reaction with diketones proceeded smoothly to yield highly functionalized products $\mathbf{4 a}$ and $\mathbf{4 b}$ in $78 \%$ and $50 \%$ yield respectively. Investigation of the reactions of donor- acceptor cyclopropanes with indoles revealed HFIP to be an inefficient solvent for such reactions, most likely owing to its ability to hydrogen bond to basic groups, thus attenuating the nucleophilicity of these species. Rather, $N$-methylindole proved a competent reaction partner with donor-acceptor cyclopropanes when employing $\mathrm{B}\left(\mathrm{C}_{6} \mathrm{~F}_{5}\right) \cdot \mathrm{H}_{2} \mathrm{O}$ as a catalyst in nitromethane, a catalytic duo previously investigated in our research group. ${ }^{11 \mathrm{a}}$ Under these conditions, products $\mathbf{4 c}$ and $\mathbf{4 d}$ were delivered in 85 and $68 \%$ yield respectively. Ring opening with $\mathrm{TMS}-\mathrm{N}_{3}$ also proved facile with the developed catalytic protocol, with products $\mathbf{4 e - 4 h}$ isolated in good to excellent yield. Additionally, primary alcohols could be employed as nucleophiles with no change in reaction conditions required and products $4 \mathbf{g}-\mathbf{4 i}$ were delivered as expected in up to $90 \%$ yield (Scheme 4).

In a system designed to shed light on the mechanistic course of such cyclopropane opening reactions, treatment of enantiopure cyclopropane (S)-1a with 1,3,5-trimethoxybenzene under standard conditions delivered $(R)-\mathbf{2 a}$ in high yield. ${ }^{16}$ This observation is in line with prior Lewis acid catalyzed protocols ${ }^{8 c}$ and suggests that under Brønsted acid catalyzed conditions, cyclopropane ring-opening occurs via a predominantly $\mathrm{S}_{\mathrm{N}}$ 2-like mechanistic pathway. This allows the following mechanistic rationale to be proposed (Scheme 5). Initial protonation of the cyclopropane 'acceptor-motif" by Brønsted acid catalyst," leads to an increase in cyclopropane $C-C$ bond polarization, thus activating the benzylic carbon to nucleophilic attack by the nucleophilic species in a mechanism analogous to an $\mathrm{S}_{\mathrm{N}}$ 2-like displacement. Subsequent enoltautomerization or protonation, together with proton abstraction, regenerates Brønsted acid to enable turnover of the cycle and in the process delivers the desired ring-opened product.

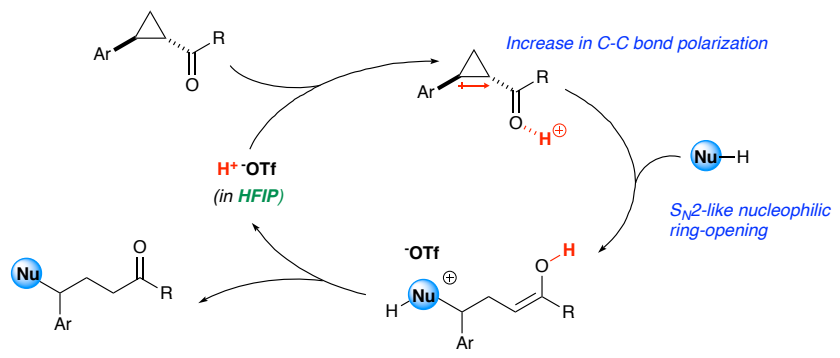

Scheme 5. A plausible mechanistic scenario.

In conclusion, a unified Brønsted acid catalyzed nucelophilic ring-opening of donor-acceptor cyclopropanes has been developed. The salient features of this system are the operatorfriendly reaction procedure, and the wide scope with respect to both the cyclopropane scaffold and nucleophile. The combination of TfOH and HFIP provide a simple yet highly active Brønsted acid system allowing novel classes of cyclopropane, including those bearing electron-deficient aryl groups and those derived from chalcones, to engage in nucleophilic ringopening reactions for the first time. Initial observations suggest that ring-opening occurs via an $\mathrm{S}_{\mathrm{N}} 2$-like mechanistic pathway, however comprehensive mechanistic studies into the Brønsted acid catalyzed activation of a range of small-ring cycloalkyl-species are currently ongoing within our laboratory, and will be reported in due course.

\section{ASSOCIATED CONTENT}

\section{Supporting Information}


The Supporting Information is available free of charge on the ACS Publications website.

Optimization data, experimental procedures, characterization of new compounds, and spectral data (PDF)

\section{AUTHOR INFORMATION}

\section{Corresponding Author}

*moran@unistra.fr

\section{Author Contributions}

The manuscript was written through contributions of all authors. / All authors have given approval to the final version of the manuscript.

\section{ACKNOWLEDGMENT}

This project has received funding from the European Research Council (ERC) under the European Union's Horizon 2020 research and innovation programme (grant agreement $n^{\circ}$ 639170) and by grants from LabEx "Chemistry of Complex Systems". V.D.V. thanks the French government for an MRT fellowship. We thank Dr Helmut Muenster of MasCom and Dr Jean-Louis Schmitt (ISIS, CNRS, UMR7006) for their assistance with HRMS analysis.

\section{REFERENCES}

1) For reviews on D-A cyclopropanes, see: a) Reissig, H.-U.; Zimmer, R. Chem. Rev. 2003, 103, 1151. b) Yu, M.; Pagenkopf, B. L. Tetrahedron, 2005, 61, 321. c) Schneider, T. F.; Kaschel, J.; Werz, D. B. Angew. Chem. Int. Ed. 2014, 53, 5504. d) M. A. Cavitt, M. A.; Phun, L. H.; France, S. Chem. Soc. Rev. 2014, 43, 804. e) Grover, H. K.; Emmett, M. R.; Kerr, M. A. Org. Biomol. Chem. 2015, 13, 655. e) O' Conner, N. R.; Wood, J. L.; Stoltz, B. M. Isr. J. Chem. 2016, 56, 431. f) Budynina, E. M.; Ivanov, K. L.; Sorokin, I. D.; Melnikov, M. Y. Synthesis, 2017, 3035.

2) For selected examples of D-A cyclopropanes engaging in catalytic [3+2]-cycloadditions, see: a) Pohlhaus, P. D.; Johnson, J. S. J. Am. Chem. Soc. 2005, 127, 16014; b) Pohlhaus, P. D.; Sanders, S. D.; Parsons, A. T.; Li, W.; Johnson, J. S. J. Am. Chem. Soc. 2008, 130, 8642; c) Jackson, S. K.; Karadeolian, A.; Driega, A. B.; Kerr, M. A. J. Am. Chem. Soc. 2008, 130, 4196; d) Parsons, A. T.; Johnson, J. S. J. Am. Chem. Soc. 2009, 131, 3122; e) Xing, S.; Pan, W.; Liu, C.; Ren, J.; Wang, Z. Angew. Chem. Int. Ed. 2010, 49, 3215; f) Parsons, A. T.; Smith, A. G.; Neel, A. J.; Johnson, J. S. J. Am. Chem. Soc. 2010, 132, 9688; g) de Nanteuil, F.; Waser, J. Angew. Chem. Int. Ed. 2011, 50, 12075; h) Xu, H.; Qu, J.; Liao, S.; Xiong, H.; Tang, Y. Angew. Chem. Int. Ed. 2013, 52, 4004; i) de Nanteuil, F.; Serrano, E.; Perrotta, D.; Waser, J. J. Am. Chem. Soc. 2014, 136, 6239; j) Cui, B.; Ren, J.; Wang, Z. J. Org. Chem. 2014, 79, 790; k) Zhu, J.; Liang, Y.; Wang, L.; Zheng, Z.; Houk, K. N.; Tang, Y. J. Am. Chem. Soc. 2014, 136, 6900. 1) Garve, L. K. B.; Kreft, A.; Jones, P. G.; Werz, D. B. J. Org. Chem. 2017, 82, 9235. m) Augustin, A. U.; Sensse, M.; Jones, P. G.; Werz, D. B. Angew. Chem. Int. Ed. 2017, 56, 14293. For selected examples of D-A cyclopropanes engaging in catalytic [3+3]-cycloadditions, see: n) Young, I. S.; Kerr, M. A. Angew. Chem. Int. Ed. 2003, 42, 3023; o) Sibi, M. P.; Ma, Z.; Jasperse, C. P. J. Am. Chem. Soc. 2005, 127, 5764; p) Kang, Y.; Sun, X.;. Tang, Y. Angew. Chem. Int. Ed. 2007, 46, 3918; q) Dias, D. A.; Kerr, M. A. Org. Lett. 2009, 11, 3694; r) Humenny, W. J.; Kyriacou, P.; Sapeta, K.; Karadeolian, A.; Kerr, M. A. Angew. Chem. Int. Ed. 2012, 51, 11088; s) Zhou, Y.; Li, J.; Ling, L.; Liao, S.; Sun, X.; Li, Y.; Wang, L.; Tang, Y. Angew. Chem. Int. Ed. 2013, 52, 1452; t) Zhang, H.; Luo, Y.; Wang, H.; Chen, W.; Xu, P. Org. Lett. 2014, 16, 4896; u) Liu, H.; Yuan, C.; Wu, Y.; Xiao, Y. Guo, H. Org. Lett. 2015, 17, 4220. v) Chidley, T.; Vemula, N.; Carson, C. A.; Kerr, M. A.;
Pagenkopf, B. L. Org. Lett. 2016, 81, 3917. For selected examples of D-A cyclopropanes engaging in catalytic [3+4]cycloadditions, see: see: w) Ivanova, O. A.; Budynina, E. M.; Grishin, Y. K.; Trushkov, I. V.; Verteletskii, P. V. Angew. Chem. Int. Ed. 2008, 47, 1107; x) Xu, H.; Hu, J.; Wang, L.; Liao, S.; Tang, Y. J. Am. Chem. Soc. 2015, 137, 8006. y) Garve, L. K. B.; Pawliczek, M.; Wallbaum, J.; Jones, P. G.; Werz, D. B. Chem. Eur. J. 2016, 22, 521.

3) For recent examples, see: a) Garve, L. K. B.; Barkawitz, P.; Jones, P. G.; Werz, D. B. Org. Lett. 2014, 16, 5804. b) Banik, S. M.; Mennie, K. M.; Jacobsen, E. N. J. Am. Chem. Soc. 2017 , 139, 9152. c) Wallbaum, J.; Garve, L. K. B.; Jones, P. G.; Werz, D. B. Org. Lett. 2017, 19, 98.

4) For a comprehensive account and mechanistic study into the addition of $\mathrm{H}-\mathrm{X}$ to cyclopropanes, see: Lambert, J. B.; Napoli, J. J.; Johnson, K. K.; Taba, K. N.; Packard, B. S. J. Org. Chem. $\mathbf{1 9 8 5}, 50,1291$.

5) For the use of thiols as nucleophiles, see: a) Braun, C. M.; Sherma, A. M.; Dulin, C. C.; Nolin, K. A. Tetrahedron Lett. 2013, 54, 5889. b) Wang, H.-P.; Zhang, H.-H.; Hu, X.-Q.; Xu, P.-F.; Luo, Y.-C. Eur. J. Org. Chem. 2015, 3486. For ring opening with bromide, see: c) Xu, W.; Dolbier Jr, W. R.; Salazar, J. J. Org. Chem. 2008, 73, 3535. For ring-opening with azides, see: d) Emmett, M. R.; Grover, H. K.; Kerr, M. A. J. Org. Chem. 2012, 77, 6634. e) Ivanov, K. L.; Villemson, E. V.; Budynina, E. M.; Ivanova, O. A.; Trushkov, I. V.; Melnikov, M. Y. Chem. Eur. J. 2015, 21, 4975. For ring-opening with phenolates, see: f) Lifchits, O.; Alberico, D.; Zakharian, I.; Charette, A. B. J. Org. Chem. 2008, 73, 6838. For reaction with amines, see: g) Blanchard, L. A.; Schneider, J. A. J. Org. Chem. 1986, 51, 1372. h) Lichfits, O.; Charette, A. B. Org. Lett. 2005, 7, 2313. i) Lifchits, O.; Charette, A. B. Org. Lett. 2008, 10, 2809. j) Martin, M. C.; Patil, D. V.; France, S. J. Org. Chem. 2014, 79, 3030. k) Zhou, Y.-Y.; Wang, L.-J.; Li, J.; Sun, X.-L.; Tang, Y. J. Am. Chem. Soc. 2012, 134, 9066. 1) So, S. S.; Auvil, T. J.; Garza, V. J.; Mattson, A. E. Org. Lett. 2012, 14, 444. For ring-opening with organoboron reagents, see: $m$ ) Nguyen, T. N.; Nguyen, T. S.; May, J. A. Org. Lett. 2016, 18, 3786. n) Ortega, V.; Csaky, A. G. J. Org. Chem. 2016, 81, 3917. For an enantioselective multi-nucleophile (thiols, alcohols, carboxylic acids) ringopening of diketo-bearing DA-cyclopropanes, see: o) Xia, Y.; Lin, L.; Chang, F.; Fu, X.; Liu, X.; Feng, X. Angew. Chem. Int. $E d$. 2015, 54, 13748. For ring-opening reactions with silyl enol ethers, see: p) Fang, J.; Ren, J.; Wang, Z. Tetrahedron Lett. 2008, 49, 6659. q) Qu, J. P.; Liang, Y.; Xu, H.; Sun, X.-L.; Yu, Z. X.; Tang, Y. Chem. Eur. J. 2012, 18, 2196. r) Xu, H.; Qu, J.P.; Liao, S.; Xiong, H.; Tang, Y. Angew. Chem. Int. Ed. 2013, 52,4004 . For a redox/acid catalyzed, C-C bond forming reactions with naphthoquinones, see: s) Luecht, A.; Patalag, L.J.; Augustin, A. U.; Jones, P. G.; Werz, D. B. Angew. Chem. Int. Ed. 2017, 56, 10587.

6) a) Harrington, P.; Kerr, M. A. Tetrahedron Lett. 1997, 38, 5949. b) Kerr, M. A.; Keddy, R. G. Tetrahedron Lett. 1999, 40, 5671 c) Grover, H. K.; Lebold, T. P.; Kerr, M. A. Org. Lett. 2011, 13, 220. d) Wales, S. M.; Walker, M. M.; Johnson, J. S. Org. Lett. 2013, 15, 2558. e) de Nanteuil, F.; Loup, J.; Waser, J. Org. Lett. 2013, 15, 3738

7) Kim, A.; Kim, S-G. Eur. J. Org. Chem. 2015, 6419

8) a) Ivanova, O. A.; Budynina, E. M.; Grishin, Y. K.; Trushkov, I. V.; Verteletskii, P. V. Eur. J. Org. Chem. 2008, 5329. b) Jiang, X.; Lim, Z.; Yeung, Y.-Y. Tetrahedron Lett. 2013, 54, 1798. c) Talukdar, R.; Saha, A.; Tiwari, D. P.; Ghorai, M. K. Tetrahedron, 2016, 72, 613.

9) Kaicharla, T.; Roy, T.; Thangaraj, M.; Gonnade, R. G.; Biju, A. T. Angew. Chem. Int. Ed. 2016, 55, 10061.

10) The Brønsted acid catalyzed ring-opening reactions of 1-alkenyl cyclopropanes has been reported, including an example of arylative reactivity with benzene, however, most of the reported examples involve annulative type reactivity. See: a) Tsuge, O.; Kanemasa, S.; Otsuka, T.; Suzuki, T.; Bull. Chem. Soc. Jpn. 1988, 61, 2897. A single example of TfOH-catalyzed arylative 
ring-opening of a siloxy/keto donor-acceptor cycloproane has also been reported b) Wilsdorf, M.; Leichnitz, D.; Reissig, H.-U. Org. Lett. 2013, 15, 2494.

11) a) Dryzhakov, M.; Hellal, M.; Wolf, E.; Falk, F. C.; Moran, J. J. Am. Chem. Soc. 2015, 137, 9555; b) Dryzhakov, M.; Moran, J. ACS Catalysis 2016, 6, 3670. c) Dryzhakov, M.; Richmond, E.; Li, G.; Moran, J. J. Fluor. Chem. 2017, 193, 45. d) Vukovic, V. D.; Richmond, E.; Wolf, E.; Moran, J. Angew. Chem. Int. Ed. 2017, 56, 3085.

12) For examples of other HFIP-enabled strong Brønsted acid catalyzed reactions, see: a) Saito, A.; Takayama, M.; Yamazaki, A.; Numaguchi, J.; Hanzama, Y. Tetrahedron 2007, 63, 4039; b) Motiwala, H. F.; Charaschanya, M.; Day, V. W.; Aubé, J. J. Org. Chem. 2016, 81, 1593; c) Zeng, X.; Liu, S.; Xu, B. Org. Lett. 2016, 18, 4770; d) Liu, W.; Wang, H.; Li, C.-J. Org. Lett. 2016, 18, 2184; e) Kamitanaka, T.; Morimoto, K.; Tsuboshima, K.; Koseki, D.; Takamuro, H.; Dohi, T.; Kita, Y. Angew. Chem. Int. Ed. 2016, 55,15535 .

13) For studies pertaining to the properties of HFIP in the context of organic reactivity, see: a) Berkessel, A.; Adrio, J. A. J. Am. Chem. Soc. 2006, 128, 13412. b) Vuluga, D.; Legros, J.; Crousse, B.; Slawin, A. M. Z.; Laurence, C.; Bonner-Delpon, D. J. Org. Chem. 2011, 76, 1126. c) Holloczki, O.; Berkessel, A.; Mars, J.; Mezger, M.; Wiebe, A.; Waldvogel, S. R.; Kirchner, B.
ACS Catal. 2017, 7, 1846. For select, recent transformations mediated by HFIP in the absence of additional acid, see: d) Champagne, P. A.; Benhassine, Y.; Desroches, J.; Paquin, J. F. Angew. Chem. Int. Ed. 2014, 53, 13835. e) Khaskar, S. J. Fluorine Chem. 2015, 172, 51. f) Motiwaia, H. F.; Vekariya, R. H.; Aube, J. Org. Lett. 2015, 17, 5484. g) Wen, H.; Wang, L.; Xu, L.; Hao, Z.; Shao, C-L.; Wang, C. Y. Adv. Synth. Catal. 2015, 357, 4023. h) Singh, P.; Peddinti, R. K. Tetrahedron Lett. 2017, 32, 4753. i) Tang, R.-J.; Milcent, T.; Crousse, B. Eur. J. Org. Chem. 2017, 32, 4753 .

14) See the supporting information for full structural details of the cyclopropanes and for details of their preparation.

15) Using $\mathrm{TfOH}$ as a catalyst in combination with these heterocyclic substrates led to significant decomposition and lower yields of arylated products. Consequently, $\mathrm{B}\left(\mathrm{C}_{6} \mathrm{~F}_{5}\right) \cdot \mathrm{H}_{2} \mathrm{O}$ was employed as a milder Brønsted acidic catalyst.

16) See the supporting information for further details.

17) NMR titration of TfOH into a solution of cyclopropane/HFIP indeed reveals a downfield shift of cyclopropane methylene protons by ${ }^{1} \mathrm{H}$ NMR, and a downfield shift of keto-carbonyl by ${ }^{13} \mathrm{C}$ NMR. Taking together, this is highly suggestive of 'acceptor'protonation occurring facilely under the reaction conditions. 